
Social Work \& Education

(C) SW\&E, 2018

Svitlana Kalaur,

Ph.D., Associate professor,

Department of Social Pedagogics and Social Work,

Ternopil Volodymyr Hnatyuk National Pedagogical University

Ternopil, Ukraine

svitlanakalaur@gmail.com

\section{Світлана Калаур,}

кандидат педагогічних наук,

доиент,

кафедра соиіальної педагогіки $i$ сочіальної роботи,

Тернопільський нациіональний педагогічний університет імені Володимира Гнатюка

м. Тернопіль, Україна

УДК 37.091.12:364-051]:005.57

DOI: $10.25128 / 2520-6230.18 .1 .3$

Article history:

Received: February 28, 2018

1st Revision: March 13, 2018

Accepted: March 27, 2018
КОНТЕНТ-АНАЛІЗ ПРОФЕСІОГРАМИ ФАХІВЦЯ СОЦІАЛЬНОЇ СФЕРИ, КОМПЕТЕНТНОГО У РОЗВ'ЯЗАННІ ПРОФЕСІЙНИХ КОНФЛІКТІВ

АНОТАЦІЯ. У статті проаналізовано потребу у розробці професіограми фахівців соціальної сфери, яка спрямована на формування компетентності фахівців соціономічних професій у розв'язуванні конфліктів. На основі проведеного узагальнення та систематизації наукової інформації досліджено основні підходи до розробки та змісту професіограми. Обгрунтовано позицію про те, що професіограма повинна містити комплекс теоретичних знань (теоретичну компетентність), сукупність практичних умінь i навичок (процесуально-діяльнісну компетентність), охоплювати перелік професійних компетенцій, базуватися на професійно значущих якостях, професійних і особистісних характеристиках, що необхідні для ефективного розв'язування професійних конфліктів. Усі складові професіограми виступають підгрунтям для формування високого професіоналізму майбутніх фахівців соціальної сфери та безпосередньо впливають на вдосконалення їхньої готовності до розв'язання конфліктів у професійній діяльності.

Ключові слова: професіограма; теоретична компетентність; процесуально-діяльнісна компетентність; професійні компетенції; професійно значущі якості; професійні та особистісні характеристики. 


\section{Вступ}

Професійна підготовка майбутніх фахівців соціономічних професій у вищій школі нині набуває нового характеру у зв'язку з тим, що, з одного боку, більш чітко окреслені функції, завдання, обов'язки, зміст роботи, вимоги до професійноособистісних якостей; 3 другого - постійно розширюється проблемне коло професійної діяльності, яке включає нові об’єкти та нові сфери професійної діяльності та охоплює нових клієнтів. Як наслідок такого стану речей прослідковується потреба для психолога, соціального працівника та соціального педагога у сформованій готовності розв'язувати професійні конфлікти. Вагомим потенціалом у зазначеному контексті володіє професіографія. Як зазначає С. Гончаренко, на основі професіографії, можна виважено охопити різноманітні сторони конкретної професійної діяльності - соціальні, соціально-економічні, історичні, технічні, технологічні, правові, гігієнічні, психологічні, психофізіологічні й соціально-психологічні (Гончаренко, 1997, с. 275). У сучасних професіографічних дослідженнях найчастіше використовують діяльнісний підхід, який допомагає визначити основні складові елементи успішної професійної діяльності фахівців. Використання технології професіографії у баченні Є. Клімова, В.Рижикова, Н. Цигана дозволить повною мірою забезпечити оптимізацію професійної діяльності майбутніх фахівців соціономічних професій соціальної сфери щодо готовності їх до розв'язання конфліктів.

В останні десятиліття доволі популярним став контент-аналіз. Зокрема, як доводить Н. Костенко та В. Іванов, контент-аналіз - «це якісно-кількісний метод вивчення документів, який характеризується об'єктивністю висновків і строгістю процедури та полягає у квантифікаційній обробці тексту 3 подальшою інтерпретацією результатів» (Костенко, 2003, с. 44). Погоджуємося із тим, що 3 допомогою контент-аналізу можна здійснити повний цикл дослідження будь-якого документального об'єкта, він корінним чином відрізняється від інших методів дослідження документів і є самостійним шляхом наукового дослідження. Однак варто констатувати, що активно комплексний контент-аналіз з метою дослідження професіограми, яка б базувалася на формуванні готовності до розв'язання конфліктів фахівців соціальної сфери не було використано. Цей факт спонукав нас до дослідження.

Мета - охарактеризувати сутність та змістові складові професіограми.

Завдання дослідження:

- обгрунтувати потребу у розробці професіограми;

- визначити сутність наукової дефініції «професіограма» та

- розкрити зміст основних складових професіограми фахівця соціальної сфери, компетентного у розв'язанні професійних конфліктів.

\section{Методологія дослідження}

Для розв'язання поставлених завдань використано комплекс взаємопов'язаних теоретичних методів дослідження: порівняння, аналіз і узагальнення даних наукових джерел, нормативних документів - 3 метою обгрунтування доцільності розробки професіограми, уточнення ії сутності, узагальнення досвіду професійної підготовки майбутніх фахівців соціальної сфери; синтез, класифікація, систематизація - для визначення змісту основаних складових професіограми; моделювання - для розробки моделі професіограми. Використано й емпіричні методи дослідження: 
спостереження, бесіди, усне і письмове опитування для узагальнення змістових складових професіограми.

Основний акцент зроблено на використанні контент-аналізу - для виокремлення основних складових професіограми та дослідження іï змісту. Саме контент-аналіз через обгрунтованість і відтворюваність, дозволив провести повне охоплення усіх складових професіограми фахівців соціальної сфери на основі об’єктивності аналізу. Крім того, ми опиралися на таку вимогу контент-аналізу - як систематичність, тобто весь теоретичний матеріал та документи, які аналізувалися ми прагнули чітко порядкувати через категорії, що входили до складу професіограми (теоретичні знання, практичні уміння i навички, професійні компетенції, професійно значущі якості, професійні та особистісні характеристики). Причому виходили з тих міркувань, що жоден елемент професіограми не повинна випасти із аналізу. Ще одна вимога - це вимірювальність, тобто всі елементи аналізу були нами зафіксовані згідно з методикою організації та проведення контент-аналіз.

\section{Основна частина}

У своєму дослідженні ми виходили із перспектив, якими володіє контентаналіз. А саме, до уваги було взято напрацювання науковців, які позиціонують, що на основі контент-аналізу можна ефективно проводити структурування, сегментацію, розчленування інформації, яка вивчається чи вичленування із неї смислових інваріантів, які повторюються в усіх чи у ряді текстів, котрі належать до дослідницької масової сукупності (Костенко, 2003). Нині науковцями (В. Волович, В. Ядов) визначено перспективи використання контент- аналізу, до яких віднесено:

1. Рекомендується в усіх випадках, коли потрібний високий ступінь точності чи об'єктивності аналізу.

2. Застосовується при наявності великого за обсягом і несистематизованого матеріалу.

3. Корисний у тих випадках, коли категорії, важливі для цілей дослідження, характеризуються певною частотою появи у досліджуваних документах.

4. Дає добрі результати, коли велике значення для досліджуваної проблеми має джерело інформації, яке вивчається та його специфічні характеристики.

Тобто, як доводять науковці (В. Іванов, Н. Костенко, Л. Федотова) в ході процедури організації та проведення контент-аналізу аналізована наукова інформація підлягає доволі скрупульозному вивченню на основі розчленування, своєрідної вівісекції, квантифікації на ті лінгвістичні одиниці, котрі служать у тексті індикатором певних явищ дійсності, ідей, моделей поведінки. Процедура контентаналізного дослідження включає у себе як якісні, так i кількісні моменти. Відзначимо, що ми прагнули провести контент-аналіз таким чином, щоб дослідженні складові контент аналізу були адекватними по суті більш узагальненим поняттям, категоріям, явищам професіоналізму фахівців соціальної сфери, які можуть ефективно розв'язувати професійні конфлікти. Як бачимо, на перший план контент-аналізної характеристики професіограми майбутнього фахівця соціальної сфери, що володіє високим рівнем готовності до розв'язання професійних конфліктів, висувається «розчленування», - тобто певний «розклад» на реальні складові одиниці («юнітізація»), а також їх класифікація за обраними категоріями аналізу.

Під даний опис повністю підлягає дослідження професіограми майбутніх фахівців соціальної сфери. У контексті контент-аналізу доцільно насамперед 
коротко зупинитися на визначенні сутності наукової дефініції «професіограма». Так, професіограма 3 педагогічної точки зору - це своєрідний паспорт спеціальності, який віддзеркалює сукупність вимог, тобто іï кваліфікаційну характеристику, 3'ясовує обсяг i науково обгрунтоване співвідношення суспільно-політичних, спеціальних і психолого-педагогічних знань, а також комплекс умінь і навичок (Сластенин, 2002, с. 27).

У психологічному трактуванні професіограма передбачає науково обгрунтовану думку про можливі стани об'єкта та охоплює конкретні шляхи i терміни вдосконалення професійної діяльності. На думку авторів підручника 3 професіографії (Карпіловська, С. Я., 1997), професіограма - це документ, у якому подано комплексний, систематизований і всебічний опис об' єктивних характеристик професії, а також представлено сукупність вимог до індивідуально-психологічних особливостей людини, а також описані характеристики i професійно важливі особистісні якості фахівця. Погоджуємося із В. Толочеком у тому, що професіограми професій типу «людина-людина» відображають основні якісні характеристики діяльності. «Усі соціально-психологічні умови діяльності суб'єктів, як правило, складно заздалегідь передбачити, а також кількісно оцінити через високу динамічність і специфіку феноменів. Цей факт зумовлений тим, що діяльність того чи іншого фахівця багато в чому визначається формальною структурою та функціональним спектром обов'язків» (Толочек, 2005, с. 301).

Отже, можемо стверджувати, що професіограма - це зразок-орієнтир, який передбачає загальний опис професійної діяльності фахівців соціономічних професій в контексті розв'язання ними конфліктів у професійній діяльності. На ії основі можна розробити узагальнений взірець професіонала, який відповідатиме усім вимогам практики. 3 психолого-педагогічної точки зору професіограма володіє значною перспективою для розробки науково обгрунтованих i педагогічно виважених рекомендацій щодо вдосконалення професійної підготовки фахівців соціономічних професій, проектування професійного зростання на основі формування готовності до розв'язання конфліктів.

3 загальнодидактичної позиції розробка професіограми по-перше, сприятиме аналізу перспективного розвитку професій фахівців соціальної сфери; по-друге, дозволить розширити зміст професійного поля (сукупність трудових дій); по-третє, допоможе проаналізувати професійну підготовку студентів соціономічних професій; по-четверте, дасть можливість визначити професійний потенціал фахівця у якості медіатора. Методологічний потенціал від професіограми полягає у розробці адекватних методів та прийомів формування у майбутніх фахівців соціономічних професій готовності до розв'язання конфліктів та послужить стимулом підвищення пізнавальної активності у зазначеному контексті. 3 практичної точки зору, професіограма має давати відповідь на запитання: «Яка професійна діяльність аналізується, i які особливі вимоги пред'являються до фахівця, що має іiі реалізовувати?».

Передбачаємо, що виокремлення основних складових в професіограмі, які в найбільшій мірі відповідатимуть за процес формування готовності майбутніх фахівців соціальної сфери до розв'язання конфліктів у професійній діяльності, вплине на такі чинники: 1) зміцнення професійного «Я»; 2) підтримку адекватної самооцінки; 3) оперативну допомогу в професійній саморегуляції, оволодінні різними методами, способами, технологіями розв'язання професійних конфліктних ситуацій і самовдосконалення у цій площині. 
Відзначимо, що на сьогоднішній день існують різні підходи до змісту професіограми. 3 психологічної позиції, Є. Клімов радить у «формулу професії» включати предмет, мету, засоби, умови, організацію праці та спілкування у праці (Климов, 1996). У баченні автора ці параметри дають можливість охарактеризувати вимоги до майбутнього фахівця. Іншу позицію декларує В. Рижиков, який доводить, що для складання професіограми необхідно провести аналіз відповідної документації, організувати тематичні бесіди 3 компетентними фахівцями, вдаватися до включеного спостереження за професійною діяльністю успішних фахівців (Рижиков, 2010).

3 методологічної точки зору, для розробки професіограми основними орієнтирами виступали методологічні принциии комплексності, надійності, диференціації, типізації, перспективності й реальності, дотримання яких забезпечило наукову обгрунтованість усій діяльності. Отже, принцип комплексності передбачав проведення системної загальної характеристики усіх соціономічних професій (перелік обсягу знань і вмінь, ролей, вимог до майбутнього фахівця, необхідних для успішної професійної діяльності) включаючи й психограму (перелік психологічних вимог). Згідно $з$ принципом надійності, професіограма передбачала врахування ускладнених умов професійної діяльності в соціальній сфері у випадку надзвичайних умов, стихійних лих, складних життєвих обставин, у які потрапляють клієнти соціальних служб та установ. Принцип диференціації вимагає під час розробки професіограми враховувати специфіку усіх спеціальностей (соціального працівника, соціального педагога, психолога), які входять до складу соціономічних професій. На основі цього принципу розробляється весь перелік теоретичних знань, якими має оволодіти майбутній фахівець соціальної сфери під час навчання. Принцип типізації передбачає об'єднання представників різних професій у певні групи за подібністю вимог до фахівця. Цей принцип покладено в основу психологічної класифікації професій. У своїй практичній діяльності на основі принципу типізації ми використовували профорієнтаційну класифікацію типів особистості і типів професійного середовища Д. Голланда, а також класифікацію професій, запропоновану Є. Клімовим (професії типу «Людина - Людина»). Принципи перспективності й реальності обгрунтовують потребу врахування в професіографічному дослідженні тенденцій розвитку і змін у загальній структурі професій, що існують в соціальній сфері у цілому та безпосередньо тих, які спрямовані на надавання клієнтам широко спектру соціальних послуг. Вважаємо, що дотримання охарактеризованих методологічних принципів допоможе розробити якісну професіограму.

У найбільш узагальненому вигляді, на нашу думку, професіограма повинна містити комплекс теоретичних знань (теоретичну компетентність), сукупність практичних умінь $і$ навичок (процесуально-діяльнісну компетентність), охоплювати перелік професійних компетенцій, базуватися на професійно значущиих якостях, професійних $i$ особистісних характеристиках, необхідних для ефективного розв’язування професійних конфліктів.

Отже, провідною складовою професіограми $\epsilon$ теоретичні знання, які розглядаємо як особливу форму засвоєння результатів пізнання, що характеризуються усвідомленням їх істинності. Саме знання виступають складовою світогляду особистості та визначають «ставлення до дійсності, моральні погляди і переконання, вольові риси особистості, характер. Вони є одним із джерел нахилів і 
інтересів людини, необхідною умовою розвитку здібностей, обдарувань» (Професійна освіта, 2000, с. 137).

Як доводять Н. Басов, О. Беспалько, О. Іванова, О. Карпенко, Л. Міщик, T. Семигіна та ін., спектр усіх знань, якими мають опанувати майбутні фахівці соціономічних професій, доцільно поділити на такі категорії: теоретикометодологічні (знання про людину як біосоціопсихокосмічну особистість; знання закономірностей взаємодії особистості і суспільства; знання закономірностей виховання та навчання, розвитку особистості на усіх стадіях онтогенезу); методичні (знання основ методики, форм, методів, технологій діяльності з різними категоріями населення; знання практичних основ прогнозування, проектування, моделювання надання різного спектру соціальних послуг; прикладні (знання способів, прийомів, видів соціальної допомоги клієнтам, які мають особливі проблеми; знання різноманітних форм соціальної діяльності). Окремо варто наголосити на тому, що головну роль у формуванні теоретичної компетентності у розв'язанні конфліктів відводимо навчальним дисциплінам конфліктологічного спрямування, до яких відносимо: «Соціальну конфліктологію», «Соціальне партнерство», «Соціальну медіацію». Ці дисципліни забезпечують студентам соціономічних професій неперервність, ступневість та інтегрованість формування теоретичної компетентності у розв'язанні конфліктів.

Сукупність умінь та навичок складають процесуально-діяльнісну компетентність. У своєму дослідженні ми виходили 3 тих міркувань, що для якісного та успішного виконання будь-якої діяльності потрібні відповідні (загальні й спеціальні (професійній)) уміння й навики. Науковці вважають за доцільне до загальних умінь віднести гностичні, проектувальні, конструктивні, організаторські, комунікативні, оціночні, рефлексивні. Тоді як до спеціальних професійних умінь відносять комунікативні, прикладні, організаторські, аналітичні, психологопедагогічні та уміння саморегуляції. Разом узяті, вони можуть забезпечити майбутньому фахівцеві успіх у професійній діяльності. Уміння і навички повинні безпосередньо відповідати вимогам професійної діяльності та забезпечувати досягнення в ній високих результатів, визначати успіх фахівця у розв'язанні професійних конфліктів. Відзначимо, що вивчаючи дисципліни конфліктологічного спрямування, студенти соціономічних професій мають змогу опанувати ще й комплекс умінь, які безпосередньо впливають на ступінь готовності їх до розв'язання конфліктів.

Теоретична i процесуально-діяльнісна компетентність впливає на спектр професійних компетенцій майбутніх фахівців соціономічних професій. На основі порад, які задекларовано у дисертаційному дослідженні Л. Караванової (Караванова, 2012, с. 64-69), було прийнято рішення про доцільність представлення у професіограмі конкретних професійних компетенцій, що $є$ вагомими для формування у майбутніх фахівців соціальної сфери готовності до розв'язання конфліктів. До них віднесено комунікативну, організаторську, рефлексивну, аналітичну, мотиваційно-особистісну, соціальну, а саме:

- комунікативна компетенція охоплює вміння чітко висловлювати думки, аргументувати свою позицію, висловлювати судження; дозволяє встановлювати міжособистісні зв'язки, вибирати оптимальний стиль поведінки у конфлікті, організовувати діалог;

- організаторська компетенція базується на цілепокладанні та плануванні професійних дій; охоплює стійку активність, уміння керувати власною поведінкою; 
передбачає налагодження конструктивної діяльності та охоплює уміння планувати, організовувати траєкторію особистісного розвитку;

- рефлексивна компетенція регулює ступінь особистісних досягнень та спонукає до самопізнання й самовдосконалення; проявляється в умінні свідомо контролювати рівень особистісного розвитку і досягнень; передбачає сформованість толерантності, емпатії, схильності до самоаналізу;

- аналітична компетенція проявляється в комплексі умінь аналізувати, синтезувати, порівнювати, абстрагувати, узагальнювати, конкретизувати складові конфліктної взаємодії; охоплює гнучкість і критичність мислення; базується на формуванні здатності до творчої самореалізації, налагодження партнерських стосунків з колегами і клієнтами;

- мотиваційно-особистісна компетенція базується на сформованості мотиваційно-ціннісних орієнтацій; передбачає визнання значущості духовноморальних цінностей в рамках професійної діяльності; охоплює можливість працювати з клієнтом без упередженості суджень;

- соціальна компетенція виявляється в адекватності розв'язання професійних завдань, здатності взяти на себе відповідальність, спільно знаходити рішення у конфліктних ситуаціях; базується на здатності брати участь у прийнятті групових рішень; охоплює прагнення до самовдосконалення особистісного зростання та підвищення соціального статусу.

Зазначені компетенції фахівців соціальної сфери, у нашому баченні, не можна розглядати ізольовано, оскільки вони носять інтегративний, цілісний характер та $є$ продуктом професійної підготовки в контексті формування готовності до розв'язання конфліктів.

На підставі аналізу найважливіших елементів професії соціального фахівця необхідно виявляти професійні якості, що мають вирішальне значення (необхідні і бажані; провідні та несумісні; комплексні, що визначають успіх усієї діяльності у розв'язанні конфліктів) на формування високого рівня готовності до розв'язання конфліктів. Беручи до уваги той аспект, що професіограма виступає змістовою частиною професійної діяльності фахівця, вона повинна містити інформацію про те, які риси та якості притаманні людині, для досягнення позитивних результатів без шкоди для здоров'я. Вивчення напрацювань науковців дозволило нам виділити певні спільні професійні якості, які забезпечують успішність виконання професійної діяльності у контексті розв'язання конфліктних ситуацій, а саме: 1) здібності: комунікативні, організаційні, вербальні, ораторські, мисленеві, концентрація уваги, психічна та емоційна врівноваженість; 2) особистісні якості, інтереси та схильності: особистісна відповідальність, самоконтроль та врівноваженість, терпимість, інтерес та повага, винахідливість, тактовність, вихованість, цілеспрямованість, енергійність, артистизм, уміння прогнозувати події, вимогливість до себе та інших.

У найбільш загальному розумінні, враховуючи підходи провідних українських науковців, які вивчали різні аспекти професійної діяльності соціальних педагогів (Р. Вайнола, Л. Міщик, В. Поліщук, С. Харченко та ін.), соціальних працівників (І. Мельничук, О. Карпенко, Л. Тюпля та ін.), психологів (Н. Антонова, Н. Іванцова, Н. Пророк, Г. Радчук, О. Чуйко та ін.), було встановлено, що майбутнім фахівцям, котрі прийдуть на роботу в соціальну сферу, для того, щоб бути готовими до розв'язання конфліктів, повинні бути притаманні такі професійні характеристики: 
- відповідає вимогам професії (особистісний і професійний потенціал), робить певний внесок в соціальну політику і соціальну практику, ефективно розв'язуючи конфліктні ситуації;

- налаштований на професію, володіє особистісно-мотиваційною готовністю, має сформовані професійні риси та якості, позитивне ставлення до себе як до професіонала;

- уміє використовувати сучасні ефективні методи, прийоми, технології у своїй діяльності щодо розв’ язання конфліктів;

- дотримується норм, стандартів, еталонів та етичного кодексу під час розв'язання конфліктних ситуацій, усвідомлює значимість свого рішення;

- усвідомлює перспективу від використання своїх професійних знань і умінь та націлений на самовдосконалення й саморозвиток;

- володіє соціальною активністю, налаштований на пошук потенційних резервів у розв'язанні професійних конфліктів та проблем.

У нашому баченні, у професіограму майбутнього фахівця, що працюватиме у соціальній сфері та матиме сформовану готовність до розв'язання конфліктів, повинні бути внесені особистісні характеристики, які стосуються толерантності та впливають на стиль усієї професійної діяльності. Пропонуємо до основних характеристик віднести такі:

- розвиненість інтелектуальної сфери;

- гуманістичну позицію фахівця соціальної сфери;

- комунікативну активність та врахування особливостей взаємодії з клієнтами, співробітниками;

- адекватність самооцінки;

- емоційно-вольові якості і риси.

Підсумовуючи можемо зазначити, що професіограма майбутнього фахівця соціальної сфери з урахуванням сформованої готовності до розв'язання конфліктів у професійній діяльності - це багатофакторне явище, що охоплює систему теоретичної та процесуально-діяльнісної компетентності, базується на сукупності професійних компетенцій, професійних i особистісних характеристик та професійних якостей. Вважаємо, що усі іiі складові виступають підгрунтям для формування високого професіоналізму майбутніх фахівців соціальної сфери та безпосередньо впливають на вдосконалення готовності до розв'язання конфліктів у професійній діяльності.

\section{Висновки}

Як показує практика, прямо або опосередковано всі фахівці соціономічних професій дотичні до розв'язування професійних конфліктів. Розроблена професіограма базується на готовності до розв'язання конфліктів, а тому слугує орієнтиром для активізації професійної підготовки майбутніх фахівців соціальної сфери, сприяє їхній творчій самоактуалізації. Вона вступає теоретичним підгрунтям для визначення змісту, форм та методів формування готовності до розв'язання конфліктів, а також дозволяє виважено підійти до формування професійно важливих якостей, що лежать в основі успішної професійної діяльності. Виходячи з наведених аргументів, вважаємо, що розробка та впровадження професіограми дозволить вдосконалити психолого-педагогічний портрет майбутніх фахівців соціономічних професій із сформованою готовністю до розв'язання конфліктів. А тому, на відміну 
від звичайних формальних характеристик, обгрунтована професіограма може стати надійним підгрунтям для вдосконалення професійної підготовки студентів.

Результат, який очікуємо від впровадження професіограми, буде спрямований у площину загального підвищення професійної компетентності майбутніх фахівців соціальної сфери, а також на цілеспрямоване формування усіх показників готовності до розв'язання конфліктів.

\section{Література}

Гончаренко, С. У. (1997). Український педагогічний словник. К., Либідь, 376.

Караванова, Л. Ж. (2012). Профессионально-личностное развитие специалиста по социальной работе в период вузовского обучения : дисс. ... доктора психол. наук : 19.00.07. М., 410.

Карпіловська, С. Я., Мітельман, Р. І., Синявський, В. В., Ткаченко, О. М., Федоришин, Б. О., Ящишин, О. О. (1997). Основи професіографії : навч. посіб. К., МАУП, 148.

Климов Е. А. (1996). Психология профессионала: избр. психол. тр. Москва, Воронеж : Ин-т практической психологии: НПО «Модекс», 400.

Наталія Костенко, Валерій Іванов (2003). Досвід контент-аналізу: моделі та практики: [монографія]. К. : Центр вільної преси, 200 с.

Професійна освіта: Словник : навч. посіб. / уклад. Гончаренко С. У. та ін., за ред. Н. Г. Ничкало (2000). К., Вища школа, 273.

Рижиков, В.С. (2010) Теорія і практика конструювання цільових моделей (професіограм) та процесу професійної підготовки майбутніх юристів: [монографія]. Херсон : Айлан, 280.

Сластенин, В. А., Исаев, И.Ф., Шиянов, Е. Н. (2002). Педагогика : учеб. пособ. для студ. высш. пед. учеб. заведений. М., Академия, 576.

Толочек, В. А. (2005). Современная психология труда: учебн. пособие. СПб., Питер, 479. 


\title{
CONTENT-ANALYSIS OF THE PROFESSIOGRAM OF THE SOCIAL SPHERE SPECIALISTS, COMPETENT IN SOLVING PROFESSIONAL CONFLICT
}

\author{
Svitlana Kalaur, Ph.D., Associate professor, \\ Department of Social Pedagogics and Social Work Ternopil Volodymyr \\ Hnatyuk National Pedagogical University, \\ Ternopil, Ukraine \\ svitlanakalaur@gmail.com
}

\begin{abstract}
The article highlights the need for the development of the professional profile of the social sphere professionals, aimed at building their competence in the conflict resolution. The professional profile is viewed as a sample guide, which provides a general description of the professional activities of the social sphere professionals in the context of conflict resolution. From the psychological and pedagogical point of view, the professional profile is important for the development of scientifically substantiated and pedagogically sound recommendations for improving the professional training. From the didactic position, the professional profile would expand the professional field (the set of labor actions). The methodological value of the professional profile is to develop adequate methods and techniques for the development of readiness to resolve conflicts and to serve as an incentive to increase cognitive activity in the identified area. From the practical point of view, the professional profile should answer the question: "What kind of professional activity is being analyzed, and what special requirements are presented to a specialist who has to perform it?"
\end{abstract}

The main approaches to the development and content of the professional profile have been identified through the generalization and systematization of scientific information. The point of view is substantiated that the professional profile should contain the complex of theoretical knowledge (theoretical competence) and a set of practical skills and abilities (procedural and operational competence). It also should include a list of professional competences and must be based on professionally significant qualities, professional and personal characteristics necessary for effective workplace conflicts resolution. The allocation of the professional profile's components, responsible for the process of the development of readiness of future social sphere professionals to resolve workplace conflicts, would affect the following factors: 1) strengthening of professional self; 2) support of adequate self-esteem; 3) assistance in professional self-regulation, mastering methods and technologies for resolving conflict situations, and in selfimprovement.

All components of the professional profile serve as the basis for the development of highly professional future specialists in the social sphere and have a direct impact on the improvement of their readiness to resolve workplace conflicts.

Key words: professional profile; theoretical competence; competence in process and practice; professional competences; professionally meaningful qualities; professional and personal characteristics.

\section{References}


Honcharenko, S. U. (1997). Ukrainskyi pedahohichnyi slovnyk. K., Lybid, 376. [In Ukrainian].

Karavanova, L. ZH. (2012). Professional'no-lichnostnoe razvitie specialista po social'noj rabote $\mathrm{v}$ period vuzovskogo obucheniya : diss. ... doktora psihol. nauk : 19.00.07. M., 410. [In Russian].

Karavanova, L. Zh. (2012). Professyonalno-lychnostnoe razvytye spetsyalysta po sotsyalnoi rabote $\mathrm{v}$ peryod vuzovskoho obuchenyia : dyss. ... doktora psykhol. nauk : 19.00.07. M., 410. [In Ukrainian].

Klimov E. A. (1996). Psihologiya professionala: izbr. psihol. tr. Moskva, Voronezh : In-t prakticheskoj psihologii: NPO «Modeks», 400. [In Russian].

Nataliia Kostenko, Valerii Ivanov (2003). Dosvid kontent-analizu: modeli ta praktyky: [monohrafiia]. K. : Tsentr vilnoi presy, $200 \mathrm{~s}$.

Profesiina osvita: Slovnyk : navch. posib. / uklad. Honcharenko S. U. ta in., za red. N. H. Nychkalo (2000). K., Vyshcha shkola, 273. [In Ukrainian].

Ryzhykov, V.S. (2010) Teoriia i praktyka konstruiuvannia tsilovykh modelei (profesiohram) ta protsesu profesiinoi pidhotovky maibutnikh yurystiv: [monohrafiia]. Kherson : Ailan, 280. [In Ukrainian].

Slastenin, V. A. Isaev, I. F. SHiyanov, E. N. (2002). Pedagogika : ucheb. posob. dlya stud. vyssh. ped. ucheb. zavedenij. M., Akademiya, 576. [In Russian].

Tolochek, V. A. (2005). Sovremennaya psihologiya truda: uchebn. posobie. SPb., Piter, 479. [In Russian]. 
